\title{
Bordering practices in the UK welfare system
}

\author{
December 2015, accepted version, Critical Social Policy
}

Simon Guentner, Hamburg University of Applied Sciences, Germany, simon.guentner@haw$\underline{\text { hamburg.de }}$

Sue Lukes, Richard Stanton, MigrationWork CIC, London, England, sue.lukes@,migrationwork.org, richard.stanton@migrationwork.org,

\section{Bastian A. Vollmer, University of Oxford, England, bastian.vollmer@compas.ox.ac.uk}

Jo Wilding, University of Brighton, England, J.Wilding@,brighton.ac.uk

\begin{abstract}
This article considers how chauvinistic welfare policies operate as a bordering practice. Taking the UK as an example, it examines a process in which welfare provisions have increasingly been withdrawn from a group of people designated as undeserving. It points out a close link between chauvinism based on ethnicity and based on class. This relation is explored in detail for the case of social housing culminating in today's "social housing for local people" approach. A second case, access to social services for unaccompanied minors, is presented to illustrate bordering practices that operate in everyday services despite existing legal entitlements. The cases show that governments and service providers frequently act outside their legal remits to pursue this agenda, despite the UK's antidiscrimination legislation.
\end{abstract}

Keywords: immigration, welfare, benefits, housing, social services 


\section{Introduction: Bordering the welfare state - a conceptual framework}

Modern European welfare states can trace their origins back to Otto von Bismarck's paternalistic policy programmes for citizens (offering measures like accident insurance, health care, pension) that started to evolve in Prussia and Saxony in the 1840s. His intention may be called nationalistic: to discourage people from emigrating by making employment and living conditions in Prussia more attractive. But Bismarck's programmes had a protective and caring character, carried forward to the post-World War II expansion of welfare as well as universalising measures such as the United Nations Refugee Convention (1951) and Universal Declaration of Human Rights (1948).

Current welfare policy developments, in the EU and beyond, appear quite the opposite. After a neoliberal roll-back, and in an ongoing "dual crisis" of welfare states and national identities in Europe (Schierup, Hansen and Castles 2006; Jenson 2009), the very foundations of welfare provision are put in question by recent policy reforms and their underlying concepts. New exclusionary state borders are being drawn around social rights and public welfare provision, producing a 'hierarchy of citizenship' (Castles, 2007) that conflicts with human rights law and is frequently challenged by it (Blake, 2004).

A range of contributions and concepts in this field such as re-bordering (Andreas 2003), borderland (e.g. Alvarez, 1995), borderwork (Rumford, 2012) and b/order/ology (van Houtum 2010) have helped to explore and explain transformations of state borders and their significance for the affected social and territorial spaces or "borderscape" (Mazzadra and Neilson, 2013). However, ongoing reconfiguration and multiplication of borders has made them more diffuse and elusive (see also Parker and Vaughan-Williams, 2009 2012). Borders now perform "several functions of demarcation and teritorialization - between distinct social exchanges or flows, between distinct rights, and so forth" (Balibar, 2002, 76). 
We understand bordering practices as measures taken by state institutions - whether at territorial frontiers or inside them - which demarcate categories of people so as to incorporate some and exclude others, in a specific social order. Such practices are therefore 'world-configuring' (ibid), bestowing on that order both its form and its rationale.

Exploring these practices in the welfare field, we see how policy discourse about social protection has been influenced by raised public awareness of borders, driven by largely negative perceptions of migratory movements (Blinder, 2011, 2012) and by processes of securitization and militarization (e.g. Bigo, 2002; Lutterbeck, 2006; Walters 2004). Rising opposition to access to social protection for non-citizens, based on the view that "social protection should be for those who belong to the ethnically defined community and who have contributed to it" has been labelled 'welfare chauvinism' (Kitschelt, 1997: 22, see also Mewes and Mau, 2012). Attempts to explain such views include "cultural and economic conditions, but also individual perceptions and explanations", such as perceived material risk (Mewes and Mau, 2012: 150). Extending Kitschelt's definition, we interpret chauvinism as the ideological construction of a specified out-group as both threatening and morally inferior so that action to punish, exclude or incapacitate its members is necessary on both moral and existential grounds.

Bringing together the concepts above, this article focuses on the UK welfare system as a site of bordering. It shows how chauvinistic regulations and laws, alongside changing ideas of "deservingness", have been applied to determine access to social rights, and also illustrates the way this system has been implemented in practice.

The concept of welfare chauvinism is explored here in two senses:

- ethnic or national welfare chauvinism (cf. Patterson, 1977) is the attitude that migrants' access to state welfare provisions should be limited, either wholly (Koning, 2011) or 
partly (Mewes and Mau, 2012);

- class-based welfare chauvinism is the idea that welfare recipients whatever their national status are of lower value as citizens than non-recipients (cf Jones, 2012).

The concept is extended also, for our purposes, in the scope of its reference. Welfare chauvinism in our analysis is not only a public mood but also an instrument used by governments (cf. David Cameron’s “Immigration Speech” 2014, see also Anderson, 2013; McKenzie's application of the concept of "symbolic violence" to UK governments" view on poor people, McKenzie 2013: 8ff; Tyler's concept of "national abjects, Tyler 2013: 9; and the historic account of the "underclass" by Welshman 2013). We observe circular feedback between public attitudes and state action: governments not only respond to chauvinist views but, through laws and administrative practices, also themselves generate chauvinism, legitimising and rationalising popular anxiety about abuse of a publicly-funded system. The constant invention of new categories of non-citizens gives a basis to chauvinistic practices which are then enmeshed in political and public discourses.

Bordering practices built on chauvinist attitudes work on a multitude of sites where social, civic and political rights are granted, reaching beyond the use of indicators of legal residence and nationality (Guiraudon, 2000) for migrants, to signal entitlements or deservingness (Reeskens and van Oorschot, 2012) for other specified social categories such as "the unemployed", "single mothers" or "benefit claimants". This rhetorical tactic is frequently accompanied by overt scapegoating which contrasts them with other groups loosely defined in positive terms such as "hard-working families".

In the first section we seek to show how the welfare state in the UK has altered over the last 70 years in its nature and scope. We then consider factors that have driven these changes, and the way they interrelate, as they affect both UK citizens and non-citizens. 
Broadly speaking, these factors are identified at five levels, four operating nationally or supra-nationally and the fifth mainly at local level:

- Imperialist /national-chauvinist motives in the original sense: that is, belief in the superiority of one's own nation over others;

- Public anxiety or 'insecurity' about migration or about societal change more generally, sometimes encouraged by politicians or media;

- Fiscal pressures forcing or justifying 'welfare retrenchment', translating into cuts in government expenditure nationally and locally;

- Broader neoliberal economic strategy as initiated for the UK from 1979 onwards under the Thatcher government, aiming to marketise public services and reduce workers' bargaining power;

- Institutional factors within some local authority services, including staff prejudice and discriminatory climate, that shape the treatment of migrants.

Through this analysis we seek to assess whether welfare chauvinism can be seen meaningfully as an influence on UK policy and, if so, in what form and to what end.

Section II below outlines the historical development and current scope of the UK welfare system, and the parallel development of immigration control. It then discusses how the two developments have interacted to determine migrants' current access to welfare provisions. Section III looks in detail at migrants' access to social housing in the UK, historically and today, showing how housing practice and policy at local and national level have on occasion been driven by overt racism as well as broader welfare chauvinism. In Section IV we consider, specifically through the situation of unaccompanied children seeking asylum, how rights granted at national and international level may nevertheless be denied in practice or applied in a discriminatory manner so as to deny them to migrants. Finally Section V draws 
conclusions for the UK case, assessing how far UK welfare policy has been determined by bordering practices that apply chauvinism in either the national or the class sense.

\section{Contours of the British welfare and immigration systems}

The key point of reference for any welfare state has always been the "community of national citizens" (Bommes, 2012: 85). Citizens and other residents in a state's territory acquiesce in its political decisions in exchange for the political, legal and social security of the welfare state. The relation between national citizenship and "social citizenship" (Marshall, 1950) is complex, however, as nationality secures and defines access to some social entitlements whilst others are linked to (legal and long-term) residency.

The British welfare system has historically been considered among the most comprehensive (Mitton, 2009). After World War II, modelled on the Beveridge Report (1942), it offered free access to health care by a National Health Service (NHS); free education up to age 15; and a government commitment to securing full employment, public housing for rent, and social security benefits (Mitton, 2009: 478). The main pillar of social security in the UK historically was National Insurance (NI), a levy on earnings of all workers and self-employed individuals over a certain income threshold, whether nationals or not. It paid for key contributory benefits for the unemployed, sick and elderly, whilst other needs were covered by non-contributory payments such as housing benefit, income support, some disability benefits, and child benefit. The latter non-contributory benefits were typically means-tested. Over time contributory benefits have declined in value so means-tested benefits have become the main means of support and the link with NI contributions has become less significant.

The Thatcher government (1979-1990) launched a long-term project to roll back the welfare state established in 1945, with its redistribution of resources towards working-class 
citizens. This strategic project focused on 'marketising' welfare, particularly the NHS, in general under the guise of containing public expenditure (Mitton, 2009: 479, Fraser, 2009: 305ff). Its class character was vividly displayed under the Thatcher government throughout the 1980s. This period of industrial decline and rising unemployment featured a first major experiment in applying explicit chauvinism against a group of British-born citizens who were almost entirely white and working-class. Through the year-long strike by coal miners in 1984-1985 - a turning point in post-1945 UK social history - the government used the language of national mobilisation and moral condemnation against the miners and their National Union of Mineworkers, calling them "the enemy within" (Milne, 2014). This was accompanied by measures to remove benefits from strikers and their families. This internal chauvinism against UK citizens presaged moralistic attacks over following decades on other British-born groups such as single mothers and the long-term unemployed.

Immigration policy over the corresponding period was at first relatively open. From the immediate post-war years until 1962, British empire subjects and Commonwealth citizens were encouraged to migrate to the UK. Thus while welfare had a nationalist character (National Health Service, National Insurance), nationality was an inclusive concept available to a great many migrants.

Even in this early period however, reality diverged from these principles. Alhough on paper Commonwealth immigrants had free access to the UK until 1962, this was merely an "illusion" (Spencer, 2012: 24) as government oficials "raised the invention of techniques to keep Britain white without using legislation almost to the level of an art form” (Spencer, 1997: 153). The Commonwealth Immigrants Act 1962, restricting access through a system of employment vouchers, was followed by the 1971 Immigration Act which "consolidated the now tight restrictions on all primary immigration, allowing access for work only through a work permit system linked to specific jobs" (Spencer, 2012: 26). This sequence of laws to 
control and manage migration flows illustrates the way changing political concerns led to a complex system of status and stratification amongst Britain's immigrant population.

They also show the long history of chauvinism against migrants and its firm grip on both the UK's dominant political parties, Labour and Conservative. Labour's “enthusiasm for controls" in the 1970s was exceeded by the Thatcher government's 1981 Nationality Act "redefining British citizenship more narrowly to match those who now had the right to live in the UK and creating subcategories of citizenship for many who did not" (Spencer, 2012: 28). In the 1990s, three laws on asylum and immigration further restricted access to welfare benefits and services: the Asylum and Immigration Appeals Act 1993; the Asylum and Immigration Act 1996 under a Tory government; and Labour's Immigration and Asylum Act 1999. With accompanying political noise, these laws "portrayed asylum seekers as undeserving, a drain on a welfare state to which they had not contributed" (Spencer, 2012: 52; MacDonald and Billings, 2007). The tough stance was later defended by the Labour government of Tony Blair (1997-2007) as a necessary step to keep public order and to damp down racism: "unless we act to tackle abuses it could easily be exploited by extremists to promote their perverted view of race" (Home Office, 2005 quoted in Spencer, 2012: 53). But Blair's intense focus on immigration control in the late 1990s and 2000s meant that restrictive measures against migrants accelerated during this period, while economic expansion helped to mask more general, class-based welfare retrenchment.

Thus it can be seen that the class project and the migration control project have evolved roughly in tandem over the period since 1945, with the former at least partly driving the latter. The rationale of public welfare has shifted from the founding principle, "from cradle to grave" (Attlee government 1945-51) to the concept "from welfare to work" under Blair. Meanwhile xenophobic or nationalist rhetoric was driving and rationalising the evolution of migration control and chauvinist policies on migrants' access to welfare 
provisions. As a consequence "in a situation of growing inequality and social exclusion, it is the ethnic minorities who have fared the worst (...) despite four decades of antidiscrimination legislation" (Schierup, Hansen and Castles, 2006: 136).

For EU migrants in the UK, it might be assumed, access to welfare provisions on an equal basis to British nationals would be assured by EU rules and foundational principles guaranteeing the status of EU citizens as distinct from third-country nationals.

Their rights have however become an arena for political debate and new bordering practices, mainly since the accession of eight new EU member states in 2004. The ensuing decade saw a series of bordering measures against them, changing definitions and entitlement to impede practical access to EU Treaty rights. In 2013 the rules on benefits for job-seekers were amended in a move openly aimed at preventing EEA nationals from accessing them within and beyond a certain period ${ }^{1}$. The amended Regulations changed the definition of worker and job-seeker, two of the categories of "qualified person" who under EU rules would have the right to reside in the UK. Without that right, the person is deemed not habitually resident - regardless of how long they have in fact lived in the UK - which in turn disqualifies them from receiving benefits.

A similar bureaucratic ruse was used to exclude from the welfare system non-EU nationals caring for a British child. In 2011 the European Court of Justice ruled that governments must give residence cards to such parents if they would otherwise be forced to leave the EU. ${ }^{2}$ The UK then amended its social security and housing regulations ${ }^{3}$ to specify that parents in this category - despite the residence card now permitting them to live and work in the UK - were not entitled to means-tested benefits, social housing or homelessness assistance. 
Another more far-reaching form of bordering is the extension of the requirement "No Recourse to Public Funds" (NRPF), that is, exclusion from most state support. This condition has long been applied to those entering the UK under rules which required proof of adequate maintenance and accommodation, such as the spouse or student categories (cf Sirriyeh, 2015). But in December 2012 Immigration Rules were changed to impose the NRPF condition also on migrants who secured limited leave to remain in the UK on the grounds of long residence in the $\mathrm{UK}$.

Family relationships, once again, took the impact of this change. The premise for long residence leave is often that the applicant has a child (British or not) who has been resident for a long time in the UK. Imposing the NRPF condition meant for example that a disabled single mother who was unable to work, with two children who had lived most or all of their lives in the UK, could not access any benefits. A single parent with young British children could not claim even Child Benefit or Tax Credits for children because the parent was barred from recourse to public funds. Staying in employment is unlikely to be feasible for such a parent - unless in a high-waged job - without state support such as Working Tax Credit to help with the UK's high child-care expenses.

In this way the NRPF condition was used for the first time to deny social rights not to people seeking to enter but to a cohort of people already in the UK, creating a new form of exclusion of those whose physical presence was only grudgingly permitted. The courts subsequently ruled however that this condition was unlawful in respect of anyone with a characteristic protected by the Equality Act 2010, including disability and gender. This should mean that single mothers are exempt from the NRPF condition where, because of child care costs, in-work benefits are necessary for them to take up employment. 
The law in theory offers a further "safety net" for people with children who are denied access to the national welfare system. To secure the welfare of the child, local authorities have a duty under section 17 of the Children Act 1989 to provide a minimum subsistence allowance for destitute individuals with children. Local authorities, however, have to fund this support from already overstretched budgets and often do so reluctantly, minimally and with long delays (Jennings, 2014).

Most recently, migrants have been subjected to a double charge for access to the National Health Service (NHS). Those not "ordinarily resident" in the UK could already be charged for NHS care, retrospectively for emergency treatment or in advance for nonemergency treatment. Those affected include, for example, migrants with irregular status who may have been resident in the UK for many years (section 175 of the National Health Service Act 2006). The Immigration Act 2014 (section 38) provides that all applicants for a stay of longer than six months, other than those seeking international protection (e.g. students, family members, work migrants), will have to pay an annual levy with their visa application - even though labour and family migrants will, on arrival, pay for the NHS through income tax and national insurance on the same basis as British citizens.

Unlike the NHS and welfare benefits, legal aid in the UK - state financial help to hire legal expertise in dealing with the judicial system - was not conceived as an "arm" of the welfare state, but is nevertheless a crucial adjunct to it. Whether through funding legal advice alone or through the courts, legal aid has enabled people with few resources to enforce their entitlements when denied access to services like welfare benefits, housing or community care. Severe cuts to the scope of legal aid in 2013, plus a series of cuts in payment rates, have left many people unable to access legal advice and representation (House of Commons Public Accounts Committee, 2015). This affects both citizens and non-citizens. But since all nonasylum immigration cases were removed from the scope of legal aid in April 2013, migrants 
who (for example) are wrongly refused benefits on the basis of their immigration status, are doubly disadvantaged since they cannot access advice on either issue. The government also attempted to limit eligibility for legal aid to those with at least twelve months' prior lawful residence in the UK, but this was ruled unlawful and discriminatory by the courts ${ }^{4}$.

These acts of successive governments illustrate the powerful logic of discrimination against migrants, relying on the myth of existential threats to the nation and the imagery of national defence to divide the public, especially working-class opinion. In the next two sections we take a closer look at two areas of the welfare system where in our view chauvinism is at work, limiting provision to migrants who are construed as less deserving.

\section{Locals first: welfare chauvinism in social housing}

Broadly speaking, UK housing policy - the "wobbly pillar under the welfare state" (Torgersen, 1987; Lowe, 2011: 3) - is made at national level and implemented at local level. Housing benefit (payable to households or landlords) is determined centrally but paid locally; similarly, rules for social housing allocation are set nationally and administered locally. Social housing is provided partly by local authorities and other public sector entities, partly by non-profit "housing associations". Each local authority has its own stock of social housing and/or rights to nominate households to occupy housing association properties. In 2012 social housing made up altogether $18 \%$ of dwellings in the UK (compared with $25 \%$ in 1992$)^{5}$.

Bordering has been particularly visible in the housing arm of the welfare state. We begin by tracking the progressive exclusion of migrants from social housing through both national legislation and local authority action, leading eventually to a position where even UK citizens have to demonstrate long residence in a particular area in order to access social housing there. 


\section{Bordering by redefinition}

In 1986 senior councillors in one district within London, the London Borough of Tower Hamlets (LBTH), publicly proposed a housing policy to favour "sons and daughters" of existing tenants, justified as "building more stable communities" (Local Government Chronicle, 1994). As will be seen, this council was particularly active in seeking to border out migrants from its social housing. Contrasting them with "locals", it emphasised the supposedly unreasonable demands on the borough's housing stock made by Bengalis, even though they had lived there for decades. On some occasions racist attacks, combined with an apparently discriminatory failure to re-house, had forced Bengalis out of good quality housing estates (cf. Commission for Racial Equality, 1988).

Later in the 1980s, the same borough began actively seeking to avoid housing Bengali families, particularly those where one family member had entered the UK alone for work and later needed assistance with housing when joined by other family members. The borough used the key UK policy principle that social housing cannot be offered to those who have made themselves "intentionally homeless". It declared about 60 of those families intentionally homeless (because they had left "suitable" accommodation in Bangladesh) and expelled them from temporary accommodation. It was the first time that the "intentionally homeless" designation had been used in this way.

It was longstanding law and practice, reflected in guidance from central government and the Commission for Racial Equality, that councils should not check housing applicants' immigration status. In 1988, a change in the law (Immigration Act 1988, for which LBTH had lobbied), required people to prove they could accommodate and support family members they wished to bring to the UK. LBTH then sought and obtained a court ruling that a family who had told the immigration service that they had accommodation when, in fact, 
they did not, were "illegally present" and so not entitled to housing as homeless ${ }^{6}$. As with intentional homelessness, this redefinition or expansion of illegality served to create additional internal borders. Supplementary guidance in 1994, compounded two years later by the introduction of eligibility requirements, effectively legitimised immigration checks on all applicants for homelessness services and council housing applications. In 2014 a new Immigration Act introduced the requirement that even private landlords must check would-be tenants' immigration status or face a fine. In 2015 (before the 2014 measures had even been trialled and evaluated) the government announced that it intended to supplement this with criminal proceedings that could lead to imprisonment for landlords who "persistently" failed to check immigration status. Asylum seekers were meanwhile being bordered out from the mainstream welfare state by a parallel series of legislative developments.

Their access to social housing, firstly, was restricted by redefining homelessness for asylum-seekers in the Asylum and Immigration Appeals Act 1993. Until then, asylumseekers had been treated like all other applicants for homelessness services: generally, people were legally homeless if they had lost the right to live in their previous stable home or it was unsuitable for them. Under the 1993 Act, asylum seekers were not to be regarded as homeless if they had accommodation "available to them", however temporary or unsuitable (and even if they had never lived there or were unaware of it). They also had to remain in temporary housing until their asylum case was resolved, unlike other homeless people who were offered permanent housing.

The definitive exclusion of asylum seekers (and some other migrants) from access to social housing followed with the 1996 Asylum and Immigration Act. Shortly after came the 1996 Housing Act introducing eligibility rules for all migrants and some British citizens (through the habitual residence test) which form the basis of current restrictions. Besides access to social housing, asylum-seekers also lost in 1996 the right to mainstream benefits. A 
High Court order that the government could not simply leave asylum-seekers destitute led first to an attempt to give responsibility for their support to local authorities, and then to the National Asylum Support Service launched in 2000 as a separate, more limited system of support and accommodation for asylum seekers.

Successive measures to cut access to housing for migrants over the past two decades have been underpinned by rhetoric about fairness, showing how public perceptions may be used to justify potentially discriminatory policy - even if they are known to be inaccurate. Analysing local authorities' policies for allocating social housing, in 2009, the Equality and Human Rights Commission found no evidence that migrants were favoured over UK citizens in allocating housing (Rutter and Latorre, 2009). On the contrary it found some evidence that policies may unintentionally discriminate against ethnic minority communities. Yet in the same year the government produced guidance on housing allocations (with the title "Fair and Flexible") which claimed there were "widespread perceptions that the current allocation system is unfair and favours certain groups (such as the unemployed or migrants)" (Department of Communities and Local Government 2009). Despite acknowledging that "these ... may not always be founded on fact", the government encouraged local authorities to amend allocation policies to favour certain groups of people (and, by implication, exclude others) (ibid.: 15).

Further government guidance in 2013 on housing allocation instructed local authorities to "prioritise applicants who can demonstrate a close association with their local area" (Department for Communities and Local Government, 2013: 5). It "strongly encourages" them to adopt a residency requirement of at least two years before a person could qualify for social housing (ibid.). This advice appears to have been taken with enthusiasm: many London councils now have a five year residency qualification, and one proposed ten years (Shales, 2014). For those in need of social housing, internal borders have 
thus been created not only for many migrants but also for British-born job-seekers trying to move to areas with better opportunities. ${ }^{7}$

\section{Creating and excluding the "undeserving"}

As the supply of social housing has shrunk, and as homelessness services have become mainly a mechanism for redirecting people into the private rented sector, so the mechanisms for immigration checks and controls have followed. The 2014 Immigration Act introduces a new "right to rent" tied to immigration status: it is indefinite for those with indefinite leave to remain in the UK; it is time-limited for those with limited leave to remain; and it is denied to those with no leave to remain, unless granted a discretionary right by the Home Office. This extends barriers created for social housing into private sector lettings. Private landlords are obliged by the Act to check the immigration status of all those seeking to rent including lodgers and any other adults living in a rented home, whether tenants or not.

A review of successive restrictions on acccess to local authority housing leaves an impression that sometimes measures are trialled on migrants, with a view to later extension. The 1993 redefiniton of "homelessness" for asylum seekers was later briefly applied to all applicants for help as homeless, but then withdrawn as unworkable. Another example was the government response to a court ruling that "mixed" households (where parents and children had different immigration statuses) had been discriminated against when they were refused homelessness services. In 2009, the law was amended to enable them to access the services, but differently: while other applicants for homelessness services had a very good chance of rehousing into (secure and affordable) social housing after a period in temporary accommodation, a complicated process ensured that these families received a single offer of (insecure and expensive) private rented accommodation. In 2011 the Localism Act introduced the same provisions for all homelessness applicants. With this Act, the hostile environment 
which welfare and services chauvinism had created for migrants was extended to other groups perceived as undeserving.

We can now discern the political dynamic that drives the wider process of borderingout national citizens from the welfare state. The paradigm was given (as discussed above) by the 1984-85 miners' strike in the UK: identification of an overwhelmingly British-born, white group as "the enemy within" which could then be subjected to multiple sanctions by the state. The unconcealed motive for doing so was the Thatcher government's key objective of reducing the power of trade unions and therefore working-class bargaining power, in order to create a more "flexible" labour force within the UK.

But whilst making labour easier to control, the bordering process also reflects a strategy of reducing social solidarity. The very concept of "deservingness" superimposes a moral criterion upon need. For the long-term unemployed, need arising from social disadvantage and industrial restructuring is portrayed as a moral failing. The use of language is a key tool: categories like "the workshy" and "benefit scroungers" are used repeatedly, along with explicit claims that certain groups make disproportionate demands on the taxpayer through some fault of their own (cf Anderson, 2013). They are thus separated out from the body of welfare recipients, apparently blameless, who are the originally-intended beneficiaries. Since a welfare state depends on social solidarity, it becomes possible to redraw its borders, excluding those whose moral right to that solidarity is disputed.

The transition for asylum-seekers is illustrative. During the Cold War, refugees from the then-Communist bloc (including Soviet-occupied Afghanistan) were the archetypal deserving or "genuine" migrants. As the political benefit to the UK of welcoming refugees receded, numbers of refugees began to increase. What mainly drove the developing rhetoric of hostility towards asylum-seekers with its division between "genuine" and "non-genuine", 
and the bordering of the welfare system against them, was - we argue - not rising numbers but wider political imperatives. The Conservative government from the early 1990s entered a period of disarray and asylum-seekers became a convenient scapegoat. After 1997 the Blair government, with its militarism and exploitation of nationalistic imagery, became preoccupied with showing that it could protect the UK against immigration 'abuse' through serial legislation and further bordering of welfare and asylum systems.

Using housing as an example, this section has shown that welfare chauvinism in the national /ethnic sense plainly exists within UK welfare policy: much narrower access for some people on the basis of their immigration status, often regardless of their "contribution", while asylum-seekers have been comprehensively bordered out of the welfare state. But we have also seen how the narrative of undeservingness may also be used more widely as a moralistic basis for discrimination, so measures initially targeted on migrants may be developed to exclude specific groups of national citizens from welfare provision.

\section{Access denied: Bordering in service provision for unaccompanied minors}

The case of housing illustrates the introduction of borders around certain rights by formally redefining categories of inclusion and exclusion. In this section we explore a second practice of bordering which works not by formally denying rights but rather by de facto exclusion from services. The case of unaccompanied children seeking asylum is particularly instructive because - with their obvious vulnerability as children - they retain some degree of social solidarity, yet are also tainted politically by prevailing hostility towards migrants and asylumseekers.

Unaccompanied migrant children are legally entitled to the same protections as British children in state care. The Children Act 1989 - the key domestic legislation - contains no provision for discrimination on grounds of nationality or immigration status. The UK is 
also a signatory to the UN Convention on the Rights of the Child (UNCRC) which includes the principle that the best interests of a child must be treated as a primary consideration in all decisions and actions. Though for 19 years the UK maintained an "immigration reservation" to the UNCRC, thus evading its principle of non-discrimination, this much-criticised reservation was dropped in November 2008. The UK therefore now acknowledges that it is bound by the best interests principle.

In reality the evidence suggests that misunderstanding about unaccompanied children's entitlements, within local education authorities and children's services departments, combines with anti-migrant policy trends to produce differential treatment, reinforced by a "culture of panic" in local authority social services departments starved of resources (Brownlees and Finch, 2010: 12). In Kent, the county with the highest number of unaccompanied children because of the port of Dover, social workers in the asylum team were not permitted to use foster carers on the County Council's register, meaning that the available placements were reserved for British children despite the principle that all children are entitled to the same care (Brownlees and Finch, 2010: 56).

This situation persisted in 2012 with "discriminatory treatment and a widespread lack of knowledge about [unaccompanied children]" (Dorling and Hurrell, 2012: 30). An earlier report (Crawley, 2006: 2) observed that some social workers in local authority children's services departments assumed that the provisions of the Children Acts did not apply to children who were subject to immigration control. This study also noted the "increasing expectation" from the UK government that social workers and their departments should play a role in immigration control by

- passing on information about children and young people to the Home Office

- limiting their access to housing and support and 
- assisting in assessments with a view to returning unaccompanied children to some countries of origin.

Another example is the London Borough of Hillingdon, which in 2007 was found to have a (plainly unlawful) policy of accommodating unaccompanied asylum-seeking children for a maximum of 13 weeks and then evicting them unless there was an "exceptional reason". This was an attempt to circumvent section 20 of the Children Act whereby a young person who remains a "looked-after child" for at least 13 weeks is then entitled to a range of leaving-care (longer-term support) and homelessness services from the age of 18 to at least 21 . The Borough had advised social workers against placing those children in foster care because of the "obvious problems" that would arise (Children's Commissioner, 2007: 11). Similarly some local authorities deliberately denied leaving-care services to unaccompanied asylumseeking children, by accommodating them under the more limited section 17 of the Children Act 1989 instead of section 20 (Hundt and Yazdani, 2012: 18), until the Supreme Court determined that separated children must normally be supported under section $20 .{ }^{8}$ Even those entitled to leaving-care provisions - whether they have reached 21 or not - lose all support once their immigration and asylum appeal rights are exhausted, except where this would breach their human rights. ${ }^{9}$

Another local authority proposed an overtly discriminatory policy to deal with budget cuts by cutting services to unaccompanied child asylum seekers, particularly those leaving care, including removing them from foster care earlier, increasing the number of young people supported by each staff member and reducing financial support. The authority acknowledged that this would be a two-tier service in which the Children Act duties were complied with for British children but not for migrant children, but argued that other local authorities were already operating in this way (Dorling and Hurrell, 2012: 43). 
So despite identical entitlements in law, discrimination at local authority level and lack of knowledge of entitlements at individual (professional) and institutional levels combine to deprive migrant children of their rights. Bordering in this case tends to work informally because of residual public sympathy for them as children. But with less social solidarity for them than for national looked-after children, public authorities can systematically develop policies towards this vulnerable group which are in effect chauvinistic.

\section{Conclusions: Welfare bordering in the UK}

Our introduction posited ethnicity and class-based dimensions of welfare chauvinism as a basis for bordering welfare entitlements. Focusing on the cases of housing and social services for unaccompanied minors, we have illustrated a range of practices to construct new kinds of borders that keep non-citizens at bay - less visible than those at territorial frontiers, yet highly

effective. Bordering practices may work quite subtly to achieve the simple aim of restricting access to a system to a meticulously selected category of people. In particular, this is achieved often by the bureaucratic device of redefining categories - citizenship, workers, habitual residence - so as to remove insider status from some individuals, inserting a border between them and full access.

So urgent has been the political imperative to strip migrants of social rights, that the UK government and local authorities have on many occasions been willing to step outside domestic and international legal obligations in order to do so. Whether this record of acting outside their legal powers represents a deliberate strategy or simply discriminatory blundering is a moot point. But it demonstrates both the primacy of the drive to cut public services, and the great importance of legal aid which enables individual and collective challenges to unlawful decisions. The executive arm of the state, locally and nationally, has 
demonstrated that without the oversight of the courts it is unable consistently to respect rights.

Welfare chauvinism has thus been shown to operate in practice as a form of bordering by UK authorities to exclude multiple and changing categories of migrants. These practices are not exclusive to the UK (cf. Schierup, Hansen and Castles, 2006). Efforts to impede access to benefits (child care and minimum income) can be observed across the EU, even as European institutions present evidence that immigrants are the group at most severe risk of unemployment, poverty and exclusion. But for the UK at least, we contexualise this trend in the much broader neo-liberal project of welfare retrenchment (cf Gidley and Rooke, 2010; Jones, 2012; Wiggan, 2012), effectively a class-based project to shift the shrinking residue of welfare provision from a redistributive social democratic framework into a market-based system. In this project, the "immigrant" is a particular model of undeservingness. But through political and media channels, we have argued, non-migrant social groups can also be framed within the same narrative of undeservingness and scapegoated as living off other citizens, so that social solidarity is progressively dismantled. ${ }^{10}$

Viewed through this wider lens, chauvinism against migrants emerges as a pathfinder. Rationalised by public attitudes that are themselves encouraged through political rhetoric and welfare policy, measures imposed on migrants frequently serve as a de facto "pilot" for sanctions which may in due course also be deployed against the least influential British nationals, who are selected for social bordering. Just as UK domestic politics have been deeply marked historically by Britain's global projection of military and economic power and its accompanying ideology, so the UK domestic social order now increasingly reflects bordering practices tested on those who come as migrants from the rest of the world. 


\section{Acknowledgements}

This research is a product of joint work at Migration Work CIC, London. It received no specific grant from any public, commerical or non-profit funding agency. We thank the editors of this special issue and three anonymous referees for comments to earlier versions of this article.

\section{Notes}

1. Jobseeker's Allowance (Habitual Residence) Amendment Regulations 2013 (SI 2013/3196).

2. Ruiz Zambrano (European citizenship) [2011] EUECJ C-34/09 (08 March 2011) available at: www.bailii.org/eu/cases/EUECJ/2011/C3409.html (accessed 05 April2015)

3. The Social Security (Habitual Residence) (Amendment) Regulations 2012 and the Allocation of Housing and Homelessness (Eligibility) (England) (Amendment) Regulations 2012

4. Case No: CO/17247/2013 of 15 July 2014 , available at: www.judiciary.gov.uk/wpcontent/uploads/2014/07/plp-v-ssj-and-other.pdf (access: 05 April 2015)

5. 2012 figure is for 31 March 2012. Data obtained from housing statistics by Department for Communities and Local Commuities, live tables on dwelling stock, table 101, access: 02 April 2015.

6. R v Secretary of State for the Environment ex parte London Borough of Tower Hamlets [1993] EWCA Civ

7. On 9th March 2015 the government announced that it intended to revise the guidance again to encourage greater mobility to address this problem (Department for Communities and Local Government 2015).

8. R (G) v Southwark LBC [2009] UKHL 26. For section 17 of the Children Act, see part II of this paper, above.

9. Schedule 3 to the Nationality, Immigration and Asylum Act 2002.

10. The TV documentaries "Benefits Street" and "Immigration Street" (both Channel 4, 2014) and the controversies around them are two pronounced examples for recent media attention and influence, see cf MacDonald, Shikdrick and Furlong, 2014 and Jensen, 2014. 


\section{References}

Alvarez RR (1995) The Mexican-US Border: The Making of an Anthropology of Borderlands. Annual Review of Anthropology 24: 447-470.

Anderson B (2013) Us and Them: The Dangerous Politics of Immigration Control. Oxford: Oxford University Press.

Andreas P (2003) Redrawing the line. Borders and Security in the Twenty-first Century. International Security 28(2): 78-111.

Balibar E (2002) Politics and the Other Scene. London: Verso.

Bigo D (2002) Security and Immigration: Towards a Critique of the Governmentality of Unease. Alternatives 27: 63-92.

Blake N (2004) Judicial review of expulsion decisions: reflections on the UK experience. In Dyzenhaus D (ed) The Unity of Public Law. Oxford: Hart.

Blinder S (2012) UK Public Opinion toward Immigration: Overall Attitudes and Level of Concern. Migration Observatory Briefing. Oxford: COMPAS, University of Oxford.

Blinder S (2011) Public Opinion and Public Policy: Complexities of the Democratic Mandate. Migration Observatory Policy Primer. Oxford: COMPAS, University of Oxford.

Brownlees L and Finch N (2010) Levelling the Playing Field: a UNICEF UK report into provision of services to unaccompanied or separated children in three local authority areas in England. London: UNICEF UK.

Cameron D (2014) Sppech delivered at JCB, STaffordhsire, 28 November 2014 
Castles S (2007) National and empire: hierarchies of citizenship in the new global order. In: Bertossi C (ed) EuropeanAnti-Discrimination and the Politics of Citizenship: Britain and France. Basingstoke:PalgraveMacmillan.

Children's Commissioner for England (2008) The Children's Commissioner's findings and recommendations regarding the care of unaccompanied asylum seeking children in the London Borough of Hillingdon. London: Office of the Children's Commissioner.

Commission for Racial Equality (1988) Homelessness and Discrimination: Report of a formal investigation by the CRE into the allocation of housing by the London Borough of Tower Hamlets. London: Commission for Racial Equality.

Crawley H (2006) Child first, migrant second: Ensuring that every child matters. London: Immigration Law Practitioners Association.

Department for Communities and Local Government (2009) Fair and flexible - statutory guidance on social housing allocations for local authorities in England. London: Department for Communities and Local Government.

Department for Communities and Local Government (2013) Providing Social Housing for Local People - statutory guidance on social housing allocations for local authorities in England. London: Department for Communities and Local Government.

Department for Communities and Local Government (2015) Right to Move - Response to Consultation. London: Department for Communities and Local Government.

Dorling K and Hurrell A (2012) Navigating the System: Advice provision for young refugees and migrants. London: Coram Children's Legal Centre. 
Fraser D (2009) The evolution of the British Welfare System, $4^{\text {th }}$ edition. Haundmills:

Palgrave Macmillan.

Gidley B and Rooke A (2010) Asdatown: The intersections of classed places and identities.

In: Taylor Y (ed) Classed Intersections: Spaces, Selves, Knowledges. London: Ashgate, pp.95-116.

Guiraudon V (2000) The Marshallian triptych. The role of courts and bureaucracy in furthering migrants' social rights. In: Bommes M and Geddes A (eds) Immigration and Welfare: Challenging the Borders of the Welfare State. London: Routledge, pp.72-89.

Home Office (2005) Controlling Our Borders: Making Migration Work for Britain - Five Year Strategy for Asylum and Immigration. Cm 472. London: Home Office.

House of Commons Public Accounts Committee (2015) Implementing Reforms to Civil Legal Aid $-36^{\text {th }}$ Report, 19 January.

Hundt A and Yazdani Z. (2012) Working with Migrant Children: Community care for immigration lawyers. London: Immigration Law Practitioners Association.

Jennings C (2014) Social Services Support for Destitute Migrant Families - a guide to support under s17 Children Act 1989. Public Law Project. Available at: www.publiclawproject.org.uk/data/resources/121/s-17-updated-July-2014-12.9.14.pdf (accessed 05 April 2015)

Jensen T (2014) Welfare Commonsense, Poverty Porn and Doxosophy. Sociological Research Online 19 (3), 3 
Jenson J (2009) Redesigning Citizenship Regimes after Neoliberalism. Moving towards Social Investment. In: Morel N, Palier B and Palme J (eds) What Future for Social Investment?. Stockholm: Institute for Future Studies, pp. 27-44.

Jones O (2012) Chavs. The Demonization of the Working Class. London. Verso

Koning E (2011) The real and perceived economics of immigration: Welfare chauvinism and immigrants' use of government transfers in twelve countries. In: 2011 Canadian Political Science Association. Waterloo, 16-18 May.

Local Government Chronicle (1994) Lib-Dem ‘Sons and Daughter’ Housing Policy Scrapped. 26 September: 4

Lowe S (2011) The Housing Debate. Bristol: Policy Press.

MacDonald R, Shildrick T and Furlong A (2014) 'Benefits Street' and the Myth of Workless Communities. Sociological Research Online 19 (3), 1

Macdonald I and Billings P (2007) The Treatment of Asylum Seekers in the UK. Journal of Social Welfare and Family Law 29(1): 49-65.

McKenzie L (2015) Getting By - Estates, Class and Culture in Austerity Britain. Bristol: Policy Press.

Mewes J and Mau S (2012) Welfare chauvinism, class, and economic uncertainty. In: Svallfors S (ed) Contested Welfare States. Welfare Attitudes in Europe and Beyond. Stanford, CA: Stanford University Press, pp.119-157.

Mezzadra S and Neilson B (2013) Border as Method, or, the Multiplication of Labor. Durham and London: Duke University Press. 
Milne S (2014) The Enemy Within - the secret war against the coalminers, $4^{\text {th }}$ edition.

London and New York: Verso.

Mitton L (2009) The British Welfare System - Marketization from Thatcher to New Labour. In: Schubert K, Hegelich S and Bazant U (eds) The Handbook of European Welfare States. London and New York: Routledge, pp. 478-494.

Lutterbeck D (2006) Policing Migration in the Mediterranean. Mediterranean Politics 11(1): $59-82$.

Mann M (1996) Nation-states in Europe and other continents: diversifying, developing, not dying. In: Balakrishnan G (ed) Mapping the Nation. London: Verso, pp.295-316.

Parker N and Vaughan-Williams N (2012) Critical Border Studies: Broadening and Deepening the 'Lines in the Sand' Agenda. Geopolitics 17(4): 727-733.

Parker N and Vaughan-Williams N (2009) Lines in the Sand? : Towards an Agenda for Critical Border Studies. Geopolitics 14(3): 582-587.

Patterson O (1977) Ethnic Chauvinism. The reactionary Impulse. New York: Stein and Day

Reeskens T and van Oorschot W (2012) Disentangling the 'New Liberal Dilemma': On the relation between general welfare redistribution preferences and welfare chauvinism. International Journal of Comparative Sociology 53(2): 120-139.

Rumford C (2012) Towards a multiperspectival study of borders. Geopolitics 17 (4): 887902.

Rutter J and Latorre M (2009) Social housing allocation and immigrant communities. Manchester: Equality and Human Rights Commission. 
Schierup CU, Hansen, P and Castles S (2006) Migration, Citizenship, and the European Welfare State - a European Dilemma. Oxford: Oxford University Press.

Shales M (2014) Newcomers to Barking and Dagenham to face a ten year council housing wait. Barking and Dagenham Post. 09 April.

Sirriyeh A (2015) 'All you need is love and 18,600': Class and the new UK family migration rules. Critical Social Policy 35(2): 228-247.

Spencer IRG (1997) British Immigration Policy Since 1939: The Making of Multi-Racial Britain. London: Routledge.

Spencer S (2012) The Migration Debate. Bristol: Policy Press.

Torgersen U (1987) Housing: The wobbly pillar under the welfare state. Scandinavian Journal of Housing and Planning Research Supplement 4(1): 116-127.

Tyler ( (2013) Revolting Subjects - Social Abjection and Resistance in Neliberal Britain. London: Zed Books.

van Houtum H (2010) Human blacklisting: the global apartheid of the EU's external border regime. Environment and Planning D: Society and Space 28: 957-976.

Welshman J (2013) Underclass: a history of the excluded since 1880. London: Bloomsbury.

Wiggan J (2012) Telling stories of 21st century welfare: The UK Coalition government and the neo-liberal discourse of worklessness and dependency. Critical Social Policy 32(3): $383-405$ 